\section{FEBRUARY 2010}

Tenth Annual International Symposium on Congenital Heart Disease

The Tenth Annual International Symposium on Congenital Heart Disease will be held February 6-9, 2010, at the Renaissance Vinoy Resort, St. Petersburg, Florida, USA. The Tenth Annual International Symposium on Congenital Heart Disease will focus on the latest in rare and challenging lesions. In addition to lecture presentations, the program will include lectures, handson demonstrations, panel discussions, question and answer sessions, and pathologic heart specimen exhibits. We are honored to present a distinguished faculty of domestic and international experts in Cardiology, Cardiac Intensive Care, Cardiac Anesthesia, and Cardiac Surgery for this exciting program. For more information, contact: Suzanne Anderson (telephone: 727-767-8584; E-mail: andersons@allkids.org).

\section{ESTS School of Thoracic \\ Surgery}

The ESTS School of Thoracic Surgery will be held February 15-16, 2010, in Elancourt, France. For registration and accommodation, contact: Mondial Congress and Events, Mondial GmbH \& Co. KG, Operngasse 20b, 1040 Vienna, Austria (Phone: +43 158804 0; Fax: +43 158804 0 185; E-mail: ests2010@mondialcongress.com). For information, contact: Scientific Secretariat, European Society of Thoracic Surgeons, PO Box 159, Exeter EX2 5SH, United Kingdom (Phone: +44 1392 430671;

\footnotetext{
Announcements of major meetings and other significant activities must be received at least 8 weeks before the desired month of publication. Information will be limited to title of meeting, date, place, and an address to obtain further information. Send announcements to Ryan Walther, Managing Editor, The Journal of Thoracic and Cardiovascular Surgery, 900 Cummings Center, Suite 221-U, Beverly, MA 01915 (E-mail: rwalther@prri.com).
}

Fax: +44 1392 430671; E-mail: sue @ests.org.uk; Web site: http:// www.ests.org). Additional information: http://www.estsschool.org

\section{German Society for Thoracic} and Cardiovascular Surgery

The 39th Annual Meeting of the German Society for Thoracic and Cardiovascular Surgery will be held February 14-17, 2010, at the International Congress Center Stuttgart (ICS) in Stuttgart, Germany. Abstract submission deadline: September 15, 2009. Special emphasis will be placed on Reconstructive Aortic and Mitral Valve Surgery, Interventional and Hybrid Procedures, Thoracic Aortic Aneurysm/Dissection, Long-term Outcome after Univentricular Palliation, Plastic and Reconstructive Sternal Procedures, Strategies in Treatment of the Tricuspid Valve including Ebstein, Terminal Heart Failure, and Intensive Care. Special Sessions for Nurses, Physician Assistants, and Perfusionists are also part of the program. A special Training Village with simulators and wet-labs will be available throughout the time of the meeting. Congress President is Prof. Dr Ruediger Lange, German Heart Center Munich. For information, contact: jahrestagung@dhm.mhn.de

\section{8th Utah Pediatric \\ Cardiovascular Disease \\ Conference}

Conference: February 21-25, 2010, The Cliff Lodge, Snowbird, Utah, USA. For more information, contact: Erin Schock at Pediatric Education services/Primary Children's Medical center (Telephone: 801-662-3501 or 800-910-7262; Fax: 801-662-3522; E-mail: erin.schock@imail.org).

\section{CTCOMCON 2010}

CTCOMCON 2010—Combined Annual Meeting of the Asian Society for Cardiovascular \& Thoracic Surgery (18th) and the Indian Association of Cardiovascular-Thoracic Surgeons (56th) will be held February 26 to
March 1, 2010. February 26, 2010: All India Institute of Medical Sciences; February 27-March 1, 2010: The Ashok, New Delhi, India. Abstract submission deadline: October 31, 2009. For information, contact: Conference Secretariat Dr A. Sampath Kumar, President, Organising Committee, Professor \& Head, Department of CTVS, Chief CT Centre, All India Institute of Medical Sciences, Ansari Nagar, New Delhi - 110 029, India (Telefax: +91 01126589646; Fax: +91 011-26588663; E-mail: asampath_kumar@hotmail. com or ctcomcondelhi2010@gmail. com). Additional information: http:// ctcomcon2010.com

\section{MARCH 2010}

\section{Cardiothoracic Surgery \\ Symposium}

The 30th Annual Cardiothoracic Surgery Symposium will be held March 4-7, 2010, at The Newport Beach Marriott Hotel and Marina, San Diego, California, USA. Abstract submission deadline: February 1, 2010. For information, contact: Susan Westwood, San Diego Cardiothoracic Surgery Symposium, 793-A E Foothill Boulevard, \#119, San Luis Obispo, CA 93405 (telephone: 1-805-5413118; Fax: 1-716-809-4082; E-mail: susan@amainc.com). Additional information: http://www.amainc.com/ cref_cardiothoracic.html

\section{General Thoracic Surgical Club}

General Thoracic Surgical Club will be held March 11-14, 2010, at the LaCosta Resort and Spa, Carlsbad, California, USA. CME available. For information, contact: Bonnie Lemmerman or Carla MacLean, General Thoracic Surgical Club, Mayo Clinic, 200 First Street SW, Rochester, MN 55905, USA (telephone: +1-507-538-4969; Fax:+1-507284-0058; E-mail: blemmerman@ mayo.edu or cmaclean@mayo.edu).Additional information: http://www.gtsc.org/ 


\section{ESTS School of Thoracic Surgery}

The ESTS School of Thoracic Surgery will be held March 17-21, 2010, in Antalya, Turkey. For registration and accommodation, contact: Mondial Congress and Events, Mondial $\mathrm{GmbH} \& \mathrm{Co}$. KG, Operngasse 20b, 1040 Vienna, Austria (Phone: +43 158804 0; Fax: +43 158804 0 185; E-mail: ests2010@mondialcongress.com). For information, contact: Scientific Secretariat, European Society of Thoracic Surgeons, PO Box 159, Exeter EX2 5SH, United Kingdom (Phone: +44 1392 430671; Fax: +44 1392 430671; E-mail: sue@ests.org.uk; Web site: http:// www.ests.org). Additional information: http://www.estsschool.org

\section{5th Annual Update on}

\section{Cardiopulmonary Bypass}

The 15th Annual Update on Cardiopulmonary Bypass will be held March 21-26, 2010, at the Fairmont Chateau, Whistler, British Columbia, Canada. For more information, please go to: http://www.scahq.org.

\section{APRIL 2010}

\section{The Houston Aortic Symposium: Frontiers in Cardiovascular Diseases}

The Houston Aortic Symposium: Frontiers in Cardiovascular Diseases, The Third in the Series will be held April 8-10, 2010, at The Westin Oaks Hotel, Houston, Texas, USA. Abstract submission deadline: February 26, 2010. For information, contact: Promedica International, 2333 State Street, Suite 203 (telephone: 1-760-7202263; Fax: 1-760-720-6263; E-mail: HAS2010@promedicacme.com). Addi tional information: http://www.prome dicacme.com/

\section{European Society for}

Cardiovascular Surgery-Heart and Health Foundation of Turkey

The 59th International Congress of the European Society for Cardiovascu- lar Surgery in conjunction with the 6th Congress of Update in Cardiology and Cardiovascular Surgery (UCCS) organized by Heart and Health Foundation of Turkey (HHFT) will be held April 15-18, 2010, at the Sheraton Cesme Hotel, Izmir, Turkey. All participants who registered for only the 59th ESCVS International Congress can also get free registration for the 6th Congress of Update in Cardiology and Cardiovascular Surgery. Abstracts for the ESCVS International Congress will be published in Interactive CardioVascular and Thoracic Surgery Journal. All authors with accepted abstracts are strongly recommended to submit the full manuscript of their work to the Interactive CardioVascular and Thoracic Surgery Journal, the ESCVS official journal. For information, contact: Prof Oztekin Oto, MD, FESC, FACC, Chairman of Local Organization Committee President of Congress. Additional information: http://www.tksv.org/

\section{Aortic Symposium 2010}

Aortic Symposium 2010 will be held April 29-30, 2010, at the Sheraton New York Hotel and Towers, New York City, New York, USA. Course Directors: Randall B. Griepp, MD, Mount Sinai School of Medicine and Steven L. Lansman, MD, Westchester Medical Center. Abstract submission deadline: December 11, 2009. Visit www.aats.org to learn more about submitting.

\section{MAY 2010}

\section{AATS 90th Annual Meeting}

The AATS 90th Annual Meeting will be held May 1-5, 2010, at the Metro Toronto Convention Centre, Toronto, Ontario, Canada. For more information: http://www.aats.org

\section{8th European Conference on General Thoracic Surgery}

The 18th European Conference on General Thoracic Surgery will be held
May 30-June 2, 2010, at Feria de Valladolid, Avenida Ramón Pradera s/n, 47009 Valladolid, Spain. For registration and accommodation, contact: Mondial Congress and Events, Mondial $\mathrm{GmbH} \&$ Co. KG, Operngasse 20b, 1040 Vienna, Austria (Phone: +43 1 58804 0; Fax: +43 1588040 185; Email: ests2010@mondial-congress. com). For information, contact: Scientific Secretariat, European Society of Thoracic Surgeons, PO Box 159, Exeter EX2 5SH, United Kingdom (Phone: +44 1392 430671; Fax: +44 1392 430671; E-mail: sue@ests.org.uk; Web site: http://www.ests.org). Additional information: http://www.estsmeetings. org/2010/

\section{JUNE 2010}

\section{European Society for Surgical \\ Research (ESSR) 45th Annual Congress}

The 45th Annual Meeting of the European Society for Surgical Research (ESSR) will be held June 9-12, 2010, at Centre Medical Universitaire, Geneva, Switzerland. Extended abstract submission deadline: January 10, 2010. For information, contact: Mustafa Cikirikcioglu, MD, PhD, Division of Cardiovascular Surgery, Department of Surgery, University Hospitals of Geneva Rue Gabrielle-Perret-Gentil 4, CH-1211 Genve 14, Switzerland (telephone: +41 2237276 63; Fax: +41 2237276 34; E-mail: mustafa. cikirikcioglu@hcuge.ch; Web site: www.essr2010.ch). Additional information: http://www.ctsnet.org/file/ ESSR2010announcement.pdf

\section{ISMICS 12th Annual Scientific Meeting}

The International Society for Minimally Invasive Cardiothoracic Surgery (ISMICS) 12th Annual Scientific Meeting will be held June 16-19, 2010, at the InterContinental Hotel, Berlin, Germany. The abstract submission 
site opens in early September 2009. For information, contact: EJ Weldon, 900 Cummings Center (telephone: +1 978927-8330; E-mail: ISMICS@prri.com). Additional information: http://www. ismics.org/

\section{Eighth International Symposium on Redo Cardiac Surgery in \\ Adults}

The Eighth International Symposium on Redo Cardiac Surgery in Adults will be held June 26-27, 2010, in Pittsburgh, Pennsylvania, USA. For more information, contact: Sharon Slomka, 5200 Centre Avenue, \#715, Pittsburgh, PA 15232 (telephone: 412-623-3140; fax: 412-6236431; E-mail: slomkasm@upmc.edu).

\section{SEPTEMBER 2010}

\section{5th International Meeting of the} Onassis Cardiac Surgery Center

The 5th International Meeting of the Onassis Cardiac Surgery Center: Current Trends in Cardiac Surgery and Cardiology will be held September 16-18, 2010 (NOTE DATE CHANGE) at the Eugenides Foundation Congress Center, Athens, Greece. Revised Abstract submission deadline: March 8, 2010. For information, contact: Liana Iliopoulou, Triaena Tours \& Congress, 206 Sygrou Avenue, 17672 Athens (Kallithea) (telephone:+30 210 7499353; Fax:+30 210 7705752; E-mail: lianae@triaenatours. gr). Additional information: http:// www.ocsc2010.gr/

\section{ESTS School of Thoracic Surgery}

The ESTS School of Thoracic Surgery will be held September 27-28, 2010, in Elancourt, France. For registration and accommodation, contact: Mondial Congress and Events, Mondial GmbH \& Co. KG, Operngasse 20b, 1040 Vienna, Austria (Phone: +43 158804 0; Fax: +43 158804 0 185; E-mail: ests2010@mondialcongress.com). For information, contact: Scientific Secretariat, European Society of Thoracic Surgeons, PO Box 159, Exeter EX2 5SH, United Kingdom (Phone: +44 1392 430671; Fax: +44 1392 430671; E-mail: sue @ests.org.uk; Web site: http:// www.ests.org). Additional information: http://www.estsschool.org 